\title{
軟X線・硬X線・中性子非弾性散乱を用いた 銅酸化物超伝導体のダイナミクス研究
}

\author{
日本原子力研究開発機構量子ビーム応用研究センター 石井賢司 \\ 東北大学金属材料研究所 藤田全基
}

\begin{abstract}
Kenji ISHII and Masaki FUJITA: Electron Dynamics of Copper Oxide Superconductors Studied by Soft X-ray, Hard X-ray and Neutron Inelastic Scattering

We combine soft X-ray, hard X-ray, and neutron inelastic scattering measurements to study both spin and charge excitations in electron-doped copper oxide superconductors. Thanks to the recent development of beam sources and related experimental techniques, accessible energy range of the inelastic scattering measurements overlaps each other and it enables us to investigate spin and charge dynamics in the important but unexplored energy-momentum space of the cuprate superconductors. Our study demonstrates that complementary use of X-ray and neutron has become effective in inelastic scattering for studying electron dynamics of materials.
\end{abstract}

\section{1.はじめに}

「マルチプローブ研究が拓く構造研究の新時代」という特 集への記事ということで, 執筆依頼をいただいた. 本稿での マルチプローブはX線と中性子線である. 結晶学において重 要な実験手法である回折・散乱では，X線と中性子を組み合 わせて利用することは比較的なじみやすいものと思う.どち らも波長が $1 \AA$ 程度であり, 原子間距離が同程度である結晶 の観測には都合がよいからである。両者の間の高い相補性に ついても, その時代ごとの流れに応じて議論されてきた。

1991 年には, ${ }^{1)}$ X 線の弱点である軽元素や原子番号が 近接する元素の認識を中性子で補うといった伝統的な 利用に加えて, 中性子だけでなく放射光の登場でX線で も観測が可能となった磁気回折についての相補性が詳 しく議論されている. 磁気回折について, 汎用性という 点で中性子に分があるというのは今も変わらないが，X 線では選択則によって磁性を担う電子の特異な波動関 数を決定できたというユニークな利用法も最近では報告 されている。2 加えて, フォノンについても議論されてい る。原子核を観る中性子に対し, X線では電子の振動と して観測される。さらに, 原子核や内殼電子とは異なる 価電子の振動が meV 分解能の非弾性 $\mathrm{X}$ 線散乱 (Inelastic X-ray Scattering, IXS）で観測できる可能性について記 されている. 現在, meV分解能のIXSは実現し, フォノ ンの観測も行われるようになったが, 非弾性中性子散乱 (Inelastic Neutron Scattering, INS) とIXS で得られるフォ ノンスペクトルの違いとして価電子の効果を捉えること は, 今なお興味深くチャレンジングな課題と言える.3)
1998 年に4）議論されていたものの1つは, 秩序化した 電子自由度 (電荷・スピン・軌道)の観測である。スピ ンに関して有利な中性子に対し, 共鳴X線回折によって 電荷秩序, 軌道秩序が直接的に観測できるようになっ たことが紹介されている，また，第 3 世代放射光光源を 使ってのIXSによる実験が始まってきたことから，フォ ノンに関しても詳しく議論されている。ささらに, 詳細な 議論はなされていないが, 電子状態のエネルギーレベル, すなわち, 電子励起の測定についても大いに可能性があ るだろう，という言及がある。

2015 年の本稿は, それが実現したということを示すこ とが目的である。近年の実験技術の発展により，INS と IXSが電子励起においても同じ土俵に立つことができる ようになってきた（格子ではなく）価電子を観るとい う点でのX線と中性子の相補利用は, これまでは回折実 験による静的構造にほぼ限られていたが, 非弾性散乱に よる動的構造の研究においてもそれが可能となる時代 が到来したのである、筆者らの研究グループが行った電 子ドープ系銅酸化物高温超伝導体におけるスピン・電 荷励起の研究5)を通して, マルチプローブを用いた電子 ダイナミクス研究の一端を紹介したい. 詳細は後述する が, 本研究でのX線については軟X線と硬X線の役割が 大きく異なっており, 中性子と合わせて三種のプローブ の非弾性散乱を利用したものとなっている。

\section{2. 銅酸化物高温超伝導体とそのスピン・電荷励起}

\section{1 銅酸化物高温超伝導体}

電気抵抗がゼロとなる超伝導は, ロスのない送電線や 
強力な磁石などといった応用上の重要性だけでなく基礎 科学的にも興味深い現象であり, 多くの研究者を魅了し 続けている.中でも，1986年に発見された銅酸化物にお ける超伝導は, 現在知られている物質の中で最も高い超 伝導転移温度を有しており, 発見から 25 年以上を経た 今もな㧍その発現機構解明を目指した研究が盛んに続け られている.

銅酸化物超伝導体の母物質は電子間の強い相関 （クーロン反発）に起因したモット絶縁体である。電子 は主に電気的性質を決める電荷と磁気的性質を決める スピンの2つの自由度を持っているが, 銅酸化物超伝導 体の母物質では, 電荷を動かすには $2 \mathrm{eV}$ 程度のエネル ギーギャップを越えることが必要で，それ以下のエネル ギーでは電荷自由度は凍結しているとみなせる，それに 対し，スピン自由度は生き残っており温度を下げると反 強磁性秩序が生じる, そのような母物質は, 動ける電荷 となる電子またはホールをドープすることで絶縁体か ら金属に変化し，あわせて反強磁性秩序が消失する。銅 酸化物の超伝導はそのような金属状態で起きており, そ の発現には摇らぎとして残存するスピン間の反強磁性 相関が重要な役割を果たしていると考えられている。し たがって,ドープされた電荷, および, スピンのダイナ ミクスを幅広いエネルギー・運動量空間にわたって観 測し, その全体像を明らかにすることは, 超伝導の理解 を進める上で不可欠である，とりわけ，電子ドープ系と ホールドープ系にどのような類似点, 相違点があるかを 明らかにすることは，その中心的な課題の一つである。

次に，銅酸化物を強相関電子系という超伝導とは別の 観点で考えてみる. 遷移金属酸化物などの強相関電子系 と呼ばれる物質群では, その電子状態において電子間の 強い相互作用 (多体効果) が重要となる。一体の運動と して考えることが難しく, 言わば多体問題となっている 強相関電子の運動状態をいかに記述するかは, 固体物理 学の基本的な問題である. 銅酸化物超伝導体は以下に 述べるように, 強相関電子を研究するための物質として ふさわしく，その電荷・スピン励起を実験的に明らかに することで, 電子状態を記述する理論モデルを検証する ことができる，その理由であるが，(1) 電荷自由度が凍 結し, 局在スピンモデルで記述される母物質の電子状態 がよく理解されている. (2) 電子とホールの両方がドー プ可能で, モット絶縁体から金属に至るまでドーピング 量のコントロールが可能である. (3) モットギャップ以 下の電子状態にかかわる電子の軌道が銅の $x^{2}-y^{2}$ 軌道, 酸素の $2 p$ 軌道と限られており, 比較的シンプルなモデル で議論が可能である.（4）電子の運動にかかわる相互作 用のエネルギーが大きい. 最後の点は, 高い超伝導転移 温度とも関係があるが, ここ数年の間に飛躍的に向上し たものの, IXSのエネルギー分解能が何でも測るにはま
だまだ不十分であるという実験上の制約によるものでも ある，その辺りの事情は次節で述べる。

\section{2 銅酸化物における相互作用の階層構造とスピン・ 電荷励起, 非弾性散乱}

銅酸化物の電子状態を議論する上で重要な相互作用, および，それに関係した励起 (ギャップ) のエネルギー スケールをまとめると, 図1aのような階層構造ができ上 がる. 高エネルギー側から行くと, 銅の $3 d$ 電子間のクー ロン相互作用 $(U)$ は数 $\mathrm{eV}$, それがもとになって開く母 物質の電荷移動ギャップ (銅の $x^{2}-y^{2}$ 軌道と酸素の $2 p$ 軌 道間のギャップ, $\Delta)$ は $2 \mathrm{eV}$ 程度である。，その下には, 電 子の運動エネルギーを決める移動積分 (ホッピングパラ メータ, $t$ ) が抢よそ $0.3 \sim 0.4 \mathrm{eV}$, スピン間に働く交換

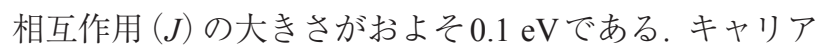
ドープされた銅酸化物の電子状態の記述にしばしば用

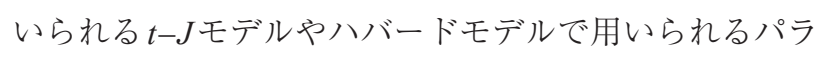
メータはちょうどこのエネルギー領域にある.フォノン や超伝導のエネルギースケールに対応する超伝導ギャッ プ $\left(\Delta_{\mathrm{sc}}\right)$ は, その下, 数十 $\mathrm{meV}$ 程度である.

この階層構造の中でドープされた電荷とスピンのダ イナミクスを考えると, その大枠を決定づけるのは, 前

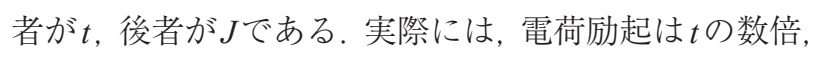
スピン励起はJの数倍に及ぶことになるので, 銅酸化物 に扮ける電子ダイナミクスの全体像を明らかにするた めには, 図1aの四角で囲んだサブ $\mathrm{eV}$ の領域を調べなけ ればならない. 結晶中でのダイナミクスの特徵となる励 起の運動量依存性を測定するとなると, 必然的に電荷に

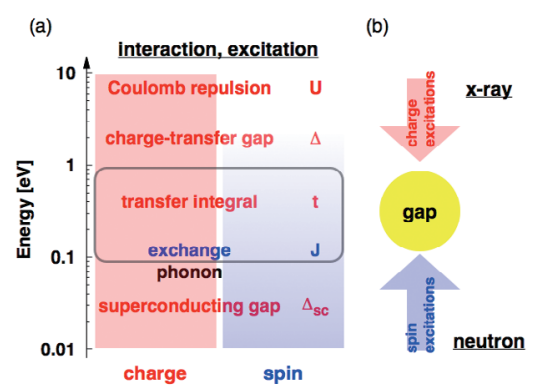

(c)

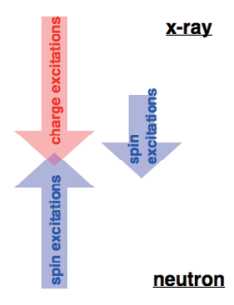

図1 銅酸化物高温超伝導体に打ける相互作用とそれ に関係した励起 (ギャップ)の階層構造. 過去 (b) と現在 (c), X線・中性子非弾性散乱で観測 可能なエネルギー範囲. (Hierarchical strucuture of electronic interactions and related excitations (gap) in copper oxide superconductor. Accessible energy range of inelastic scattering of $\mathrm{X}$-ray and neutron in the past (b) and at present (c).)（a）四角で囲んだサブ $\mathrm{eV}$ 領 域が今回の研究対象であり, 銅酸化物超伝導体に おけるドープされた電荷とスピンのダイナミクスの 大枠を決める上で重要となる. (b) 数年前までは, INS とIXS で観測できる領域にギャップがあった。 (c) 線源と測定技術の進歩によりギャップが埋ま り, INS と IXS を組み合わせることでサブ $\mathrm{eV}$ 領域 のスピン・電荷励起の研究が可能となった。 
IXS，スピンにINSを考えることになる．

しかしながら, 数年前までは, 図1bに示すように両手 法とも銅酸化物のダイナミクスを調べる上で重要なエネ ルギー領域の測定は苦手としていて, 観測可能なエネル ギー領域にもギャップがある状態であった. INSでスピ ン励起を観測することはすでに確立した技術であったも のの, 線源の強度が弱かったために $0.1 \mathrm{eV}$ 以上の励起を 観測することは, 現実的には困難であった。一方, IXSで はエネルギー分解能が不十分で, 電荷励起を観測できる のはせいぜい $1 \mathrm{eV}$ 以上に限られていた。最近になって, 中性子線源, 放射光 $X$ 線源の進歩やそれに合わせた分光 技術の発展によりこれらの欠点が克服され, 図1cのよう にギャップが埋まってきた。加えて, IXSでもスピン反 転を伴う励起が観測できることが発見され,6),7) スピン 励起だけを考えても中性子とX線をつなぎ合わせること で, サブ $\mathrm{eV}$ 領域を完全にカバーできるようになった。

ここで, 本研究で用いた共鳴非弾性X線散乱 (Resonant Inelastic X-ray Scattering, RIXS）について説明する。そ の名のとおり, RIXS はX線と内殼電子準位の共鳴効果 を利用した非弾性散乱で, 今回の研究では軟X線領域 (約 $930 \mathrm{eV}$ ) にある銅 $\mathrm{L}_{3}$ 吸収端の RIXS と硬X線領域 (約 $9000 \mathrm{eV}$ ）にある銅K吸収端のRIXSを利用した。前者は 図2aに示すように $2 p_{3 / 2}$ 軌道と $3 d$ 軌道間の双極子遷移を 利用したものである. $2 p_{3 / 2}$ 軌道の波動関数はスピン・軌 道相互作用のために上向きスピンと下向きスピンが混 じり合っているため, 入射X線で上向きスピンをもつ電 子を非占有 $3 d$ 軌道に遷移させ, 散乱 X線を放出する際 に占有 $3 d$ 軌道にある下向きスピンをもつ電子の遷移で $2 p$ 内殼正孔を埋めるという過程が許容となる。 その場合 の終状態ではスピンが反転した励起が生じることにな る. 同じ向きのスピンで遷移が起きれば, スピンを反転 しない励起 (電荷励起) が可能である.つまり, 銅 $\mathrm{L}_{3}$ 吸 収端の RIXS ではスピン励起と電荷励起の両方が観測で きる。一方, 軌道角運動量をもたない $1 s$ 軌道が遷移にか かわる銅 K吸収端の RIXSでは, スピン反転を伴う励起 は禁制で, 電荷励起のみが観測できることになる。した がって, 銅 $\mathrm{L}_{3}$ 吸収端の RIXS と銅 K 吸収端は違った役割 を担うことができ, 両者を使い分けることでスピン励起 と電荷励起の区別が可能となる.

\section{3. 実験結果}

本研究では, 軟 X線（銅 $\mathrm{L}_{3}$ 吸収端 RIXS), 硬X線（銅

$\dagger$ 全電子がかかわるフォノンを測定するための非共鳴非弾性 X線 散乱については meV分解能を達成できていた。原理的にはこ の手法で電子が1個だけかかわるような電荷励起も観測できる が, 実際には強度の問題から共鳴非弾性X線散乱を用いること になる.X線のエネルギーが元素の吸収端で決まる共鳴非弾性 X線散乱では，X線のエネルギーを自由に選べる非共鳴非弾性 $\mathrm{X}$ 線散乱とは異なる技術が必要であり, その結果として得られ るエネルギー分解能に違いが生じる.
$\mathrm{K}$ 吸収端 RIXS) には $\mathrm{Nd}_{2-\mathrm{x}} \mathrm{Ce}_{\mathrm{x}} \mathrm{CuO}_{4}(\mathrm{NCCO})$, 中性子に は $\mathrm{Pr}_{1.40-\mathrm{x}} \mathrm{La}_{0.6} \mathrm{Ce}_{\mathrm{x}} \mathrm{CuO}_{4}(\mathrm{PLCCO})$ の単結晶試料を用いた。 +3 価の $\mathrm{Nd}, \mathrm{Pr}, \mathrm{La}$ の一部を +4 価の Ceで置換すること により, $\mathrm{CuO}_{2}$ 面に電子がドープされる。 X線と中性子で 異なる試料を用いたのは, 近接する $\mathrm{Pr} の \mathrm{M}_{5}$ 吸収端が $\mathrm{Cu}$ の $\mathrm{L}_{3}$ 吸収端での RIXS の妨げになる, Ndの磁気モーメン トがINSにおけるバックグラウンドの要因になる, とい う実験上の理由であり, 今回の実験結果を議論する上で は希土類元素 $(\mathrm{Nd}, \mathrm{Pr}, \mathrm{La})$ の違いは問題にはならない.

非弾性散乱の測定は, 軟X線はESRF, ID08のAXES, 硬X線はSPring-8, BL11XUの非弾性散乱分光器, 中性

(a) Cu L 3 -edge $\left(2 p_{3 / 2} \leftrightarrow 3 d\right)$

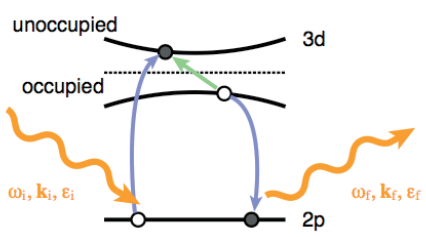

(b) Cu K-edge (1s↔4s)

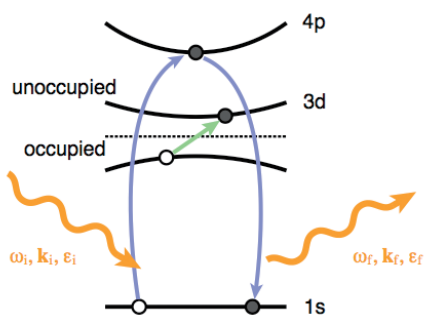

(c)

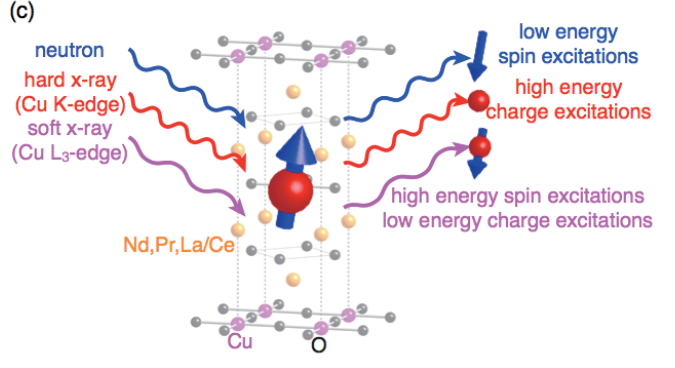

図2 RIXSの概略図と今回の実験で用いた非弾性散乱 の役割分担. (Schmatic diagrams of RIXS and role of three inelastic scattering measurements in the present study.）（a）銅 $\mathrm{L}_{3}$ 吸収端 RIXS では，エネルギー $\left(\omega_{\mathrm{i}}\right)$, 波数 $\left(\mathbf{k}_{\mathrm{i}}\right)$, 偏光 $\left(\varepsilon_{\mathrm{i}}\right)$ のX線を試料に入射し, $2 p_{3 / 2}$ 軌道にある電子が非占有 $3 d$ 軌道に遷移する。 その後, 占有 $3 d$ 状態にいた電子が $2 p_{3 / 2}$ 軌道にで きた正孔を埋めるときに, エネルギー $\left(\omega_{\mathrm{f}}\right)$, 波数 $\left(\mathbf{k}_{\mathrm{f}}\right)$, 偏光 $\left(\varepsilon_{\mathrm{f}}\right)$ の X 線を放出する. 終状態では, エ ネルギー $\omega_{\mathrm{i}}-\omega_{\mathrm{f}}$, 運動量 $\mathbf{k}_{\mathrm{i}}-\mathbf{k}_{\mathrm{f}}$ の励起が生じる。 (b) 銅 $\mathrm{K}$ 吸収端 RIXS では, $1 s$ 軌道と $4 p$ 軌道の間 の遷移を利用する。X線吸収と X線放出の中間状 態で，主に $1 s$ 内殼正孔とのクーロン相互作用によ り価電子 $(3 d$ 電子など)が間接的に励起される。 (c)今回の研究では, スピン励起は中性子が低工 ネルギー側, 軟X線が高エネルギー側, 電荷励起 は軟 X線が低エネルギー側, 硬X線が高エネル ギー側を観測した，背景にあるのは測定試料であ る $(\mathrm{La}, \mathrm{Pr}, \mathrm{Nd})_{2-\mathrm{x}} \mathrm{Ce}_{\mathrm{x}} \mathrm{CuO}_{4}$ の結晶構造である。 
子はJ-PARC，BL01の4SEASONSを使用して行った。測 定におけるそれぞれの役割は，図2cに示すように，ス ピン励起は中性子が低エネルギー側, 軟X線が高エネル ギー側, 電荷励起は軟 X線が低エネルギー側, 硬X線が 高エネルギー側となっている.

RIXS は共鳴過程を含んでいるので観測されるスペク トルがどのような物理量と関連づけられるかは必ずしも 自明ではない.しかし，本稿での議論するRIXSでは二 体相関，つまり，スピン励起は動的スピン相関，電荷励 起は動的電荷相関を観測していると考えておおむね問題 ないことが理論計算から保証されている.8)-10)

\section{1 スピン励起}

\subsection{1 軟X線非弾性散乱（銅 $\mathrm{L}_{3}$ 吸収端 RIXS）}

図3aに銅 $\mathrm{L}_{3}$ 吸収端RIXS の典型的なスペクトルを示 す. $1 \mathrm{eV}$ 以上には, 銅の占有 $3 d$ 軌道から非占有 $3 d$ 軌道 $\left(x^{2}-y^{2}\right.$ 軌道 $) \sim の$ 局所的な励起 ( $d d$ 励起) が観測される. 本研究で注目するのは, 強度にして $d d$ 励起の数分の一 である $1 \mathrm{eV}$ 以下の領域である。銅酸化物超伝導体の電 子状態は二次元性が強いため, 運動量は二次元面 $\left(\mathrm{CuO}_{2}\right.$ 面）に射影した成分 $\left(\mathbf{q}_{\|}\right)$で議論ができる。

図3bにはNCCOの運動量 $\mathbf{q}_{\|}=(0.18,0)$ におけるドー ピング依存性を示す。母物質 $(\mathrm{x}=0)$ のスペクトルは, ほかのホールドープ系の母物質7),11),12) と同様に, 弾性 散乱 (緑一点鎖線), 単一スピン反転励起 (青点線), 複

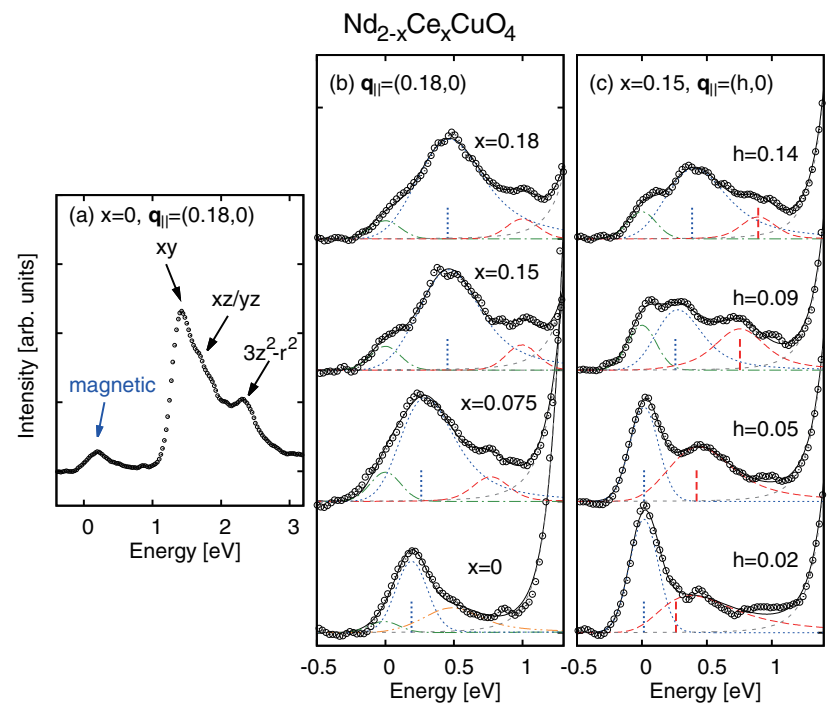

図3 $\mathrm{Nd}_{2-\mathrm{x}} \mathrm{Ce}_{\mathrm{x}} \mathrm{CuO}_{4}$ の銅 $\mathrm{L}_{3}$ 吸収端 RIXS スペクトル. $(\mathrm{Cu}$ $\mathrm{L}_{3}$-edge RIXS spectra of $\mathrm{Nd}_{2-\mathrm{x}} \mathrm{Ce}_{\mathrm{x}} \mathrm{CuO}_{4}$.) (a) 母物質 $(\mathrm{x}=0)$ の広いエネルギー範囲でのスペクトル. 1 $\mathrm{eV}$ 以上にあるのは, それぞれの図中に示した軌道 から $x^{2}-y^{2}$ 軌道への $d d$ 励起である. $1 \mathrm{eV}$ 以下には 磁気励起が観測される。 $\mathbf{q} \|$ は運動量の $\mathrm{CuO}_{2}$ 面内 成分である.(b) $\mathbf{q}_{\|}=(0.18,0)$ におけるドーピング 依存性. 青点線の棒はスピン励起のピーク位置を 表す. (c) 超伝導組成 $(\mathrm{x}=0.15)$ の運動量依存性. 青点線, 赤長破線の棒はそれぞれスピン励起, 電 荷励起のピーク位置を表す。実線はフィッティン グによる解析結果で，詳細は本文中に記す。
数のスピン反転を伴う励起 (黄色二点鎖線), $d d$ 励起 (死 色短破線）に分解できることがわかる。単一スピン反転 励起は反強磁性スピン波励起 (single magnon), 複数の スピン反転を伴う励起は主として two magnon励起によ るものであり, 前者がスペクトル強度の大部分を占めて いる，電子がドープされるにつれて，スペクトルの重心 は高エネルギー側に明瞭にシフトし, さらに幅が広がっ ていることがわかる。電子ドープした物質 $(\mathrm{x}=0.075$, $0.15,0.18)$ のスペクトルは, 弾性散乱 (緑一点鎖線), 単 一スピン反転励起 (青点線), 高エネルギー成分 (赤長破 線), $d d$ 励起 (灰色短破線) でスペクトル形状がうまく再 現できる.母物質での複数のスピン反転を伴う励起の代 わりに高エネルギー成分として別の励起を考えている が, この励起については次節で議論する. 電子ドープし た物質でも単一スピン反転励起がスペクトル強度の大部 分を占めている。通常, スピン励起と言えば, この単一 スピン反転励起を指し, INS と比較されるべきものでも あることから, 以下でも単にスピン励起と記す.

図 $4 a$ に母物質 $(x=0)$, 図4bに超伝導組成 $(x=0.15)$ の運動量・エネルギーに対する RIXS 強度マップを示す。 フィッティングによる解析で得られたスピン励起のピーク 位置を青いロで重ねてプロットしてある.母物質のスピン 励起は, 反強磁性スピン波で期待されるとおりサイン波的 な分散関係をもっている. 電子がドープされた超伝導組 成でのスピン励起では, 先に述べた高エネルギーへのシ フトと幅の広がりという特徵が見て取れる。

\section{1 .2 中性子非弾性散乱}

銅 $\mathrm{L}_{3}$ 吸収端 RIXS からは, ブリルアンゾーンの中心 $\mathbf{q}$ $=(0,0)$ 周辺のスピン励起を明らかにすることができ

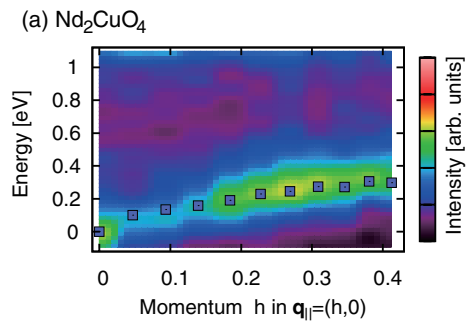

(b) $\mathrm{Nd}_{1.85} \mathrm{Ce}_{0.15} \mathrm{CuO}_{4}$

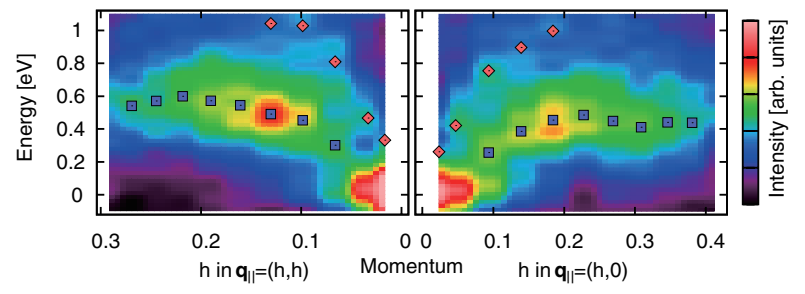

図4 $\mathrm{Nd}_{2-\mathrm{x}} \mathrm{Ce}_{\mathrm{x}} \mathrm{CuO}_{4}$ の 銅 $\mathrm{L}_{3}$ 吸収端 RIXS 強度マップ. $\left(\mathrm{Cu} \mathrm{L}\right.$-edge RIXS intensity map of $\mathrm{Nd}_{2-\mathrm{x}} \mathrm{Ce}_{\mathrm{x}} \mathrm{CuO}_{4}$.) 図中の青い口, 赤いはフィッティングによる解 析で得られたスピン励起, 電荷励起のピーク位置 を表す。

編集部注 : カラーの図はオンライン版を参照下さい. 


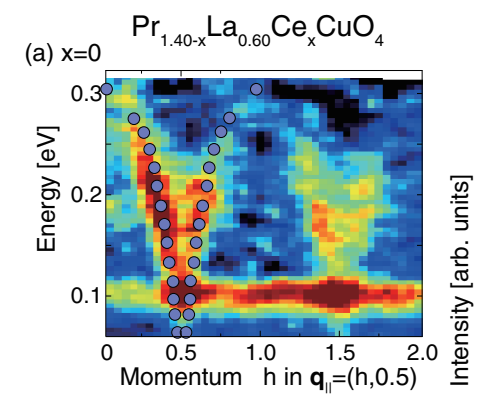

(b) $x=0.18$

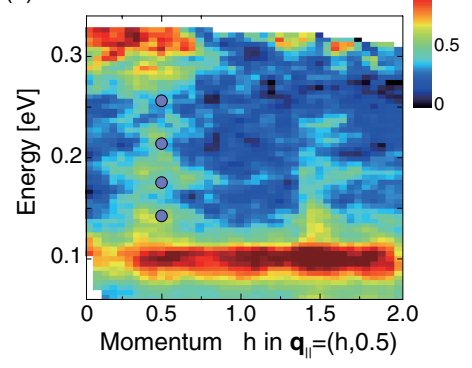

(c)

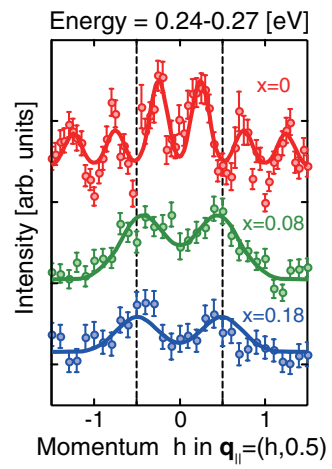

図5 $\mathrm{Pr}_{1.40-\mathrm{x}} \mathrm{La}_{0.6} \mathrm{Ce}_{\mathrm{x}} \mathrm{CuO}_{4}$ のINS 強度マップとその定エネル ギーカット. (INS intensity maps of $\mathrm{Pr}_{1.40-\mathrm{x}} \mathrm{La}_{0.6} \mathrm{Ce}_{\mathrm{x}} \mathrm{CuO}_{4}$ and their constant energy cuts.) (a,b)図中の青い はスピン励起のピーク位置を表す（c)破線は磁気 ブラッグ点 $\mathbf{q}_{\mathrm{AF}}=(0.5,0.5)$ を示す. (a)の $0.1 \mathrm{eV}$ 付 近，(b)の0.1 eVと $0.31 \mathrm{eV}$ 付近にある運動量依存 性のない励起は, 試料に含まれる希土類の結晶場 励起によるものである。

編集部注：カラーの図はオンライン版を参照下さい.

た. 一方, INSでは, 母物質の反強磁性ブラッグ点 $\mathbf{q}_{\mathrm{AF}}=$ $(0.5,0.5)$ 近傍门の, 銅 $\mathrm{L}_{3}$ 吸収端 IXS よりは低エネルギー のスピン励起を議論する.

図5aに母物質 $(x=0)$, 図5bに電子をドープした物 質 $(\mathrm{x}=0.18)$ の INSの強度マップを示す. 図 $5 \mathrm{a} の 0.1 \mathrm{eV}$ 付近, 図 $5 \mathrm{~b}$ の $0.1 \mathrm{eV}$ と $0.31 \mathrm{eV}$ 付近にある運動量依存性 のない励起は, 試料に含まれる希土類の結晶場励起によ るもので, ここでは無視する. 母物質の $\operatorname{Pr}_{1.60} \mathrm{La}_{0.40} \mathrm{CuO}_{4}$ では, $\mathrm{Nd}_{2} \mathrm{CuO}_{4}$ と同様, 反強磁性スピン波が観測されて いる，そのピーク位置を図中に重ねてプロットすると青 い○のようになり, $\mathrm{Nd}_{2} \mathrm{CuO}_{4}$ のスピン波分散とほぼ一致 する。この結果は, IXSで測定したNCCOと INSで測定 したPLCCOの間でスピン励起の比較が有意であること

†銅 $\mathrm{L}_{3}$ 吸収端（約 $933 \mathrm{eV}$ )のX線は, 波長が長過ぎるために $\mathbf{q A F}_{\mathrm{AF}}$ ま では測定することができない.
の根拠となる。

電子がドープされると, $0.1 〜 0.3 \mathrm{eV}$ の強度は $\mathbf{q}_{\mathrm{AF}}$ に集 中し, $\mathbf{q}_{\|}=\mathbf{q}_{\mathrm{AF}}$ から急峻に立ち上がる励起に変化する. 筆者らのグループがこのような $\mathbf{q}_{\mathrm{AF}}$ から急峻に立ち上が る励起がおよそ $0.18 \mathrm{eV}$ まで存在していることを過去の INSの実験から報告していたが,13) 今回の研究で, それが さらに $0.3 \mathrm{eV}$ 付近まで続いていることが明らかになった。 図3cには, $0.24 \sim 0.27 \mathrm{eV}$ の強度を積分して運動量に対 してプロットした結果を示す.母物質では, $\mathbf{q}_{\|}=(0.25,0)$ とその等価な位置にピークがあるが, 電子ドーピングが 進むにつれて, ピーク位置が $\mathbf{q}_{\mathrm{AF}} に$ 向けてシフトしてい く様子がわかる，別の言い方をすれば，ある運動量で固 定してみると, ドーピングによって励起が高エネルギー にシフトしているということになり, 銅 $\mathrm{L}_{3}$ 吸収端 RIXS で観測された特徴をINSでも捉えたことになる。

\section{2 電荷励起}

\subsection{1 硬X線非弾性散乱（銅K吸収端RIXS）}

少し古い研究であるが本研究の議論に必要なので, 以 前の NCCOに対する銅K吸収端RIXS の研究結果につ いて触れておく8 $\left.{ }^{8}, 14\right)$ 図 $6 \mathrm{a} に \mathbf{q} \|=(0.25,0)$ で比較した NCCOのスペクトルを示す. 先に述べたとおり, 銅K吸 収端RIXS では電荷励起のみが観測される。

モット絶縁体である母物質 $(\mathrm{x}=0)$ では明瞭なギャッ プが観測されており, 電荷を動かすにはこのギャップを 越えるエネルギーが必要となる。電子がドープされると $1 \mathrm{eV}$ 付近に励起が現れる。そその強度がほぼ電子濃度 $(\mathrm{x})$ に比例していることから, ドープされた電荷に関係した 励起である。われわれは，これを銅の上部ハバードバン ドにおけるバンド内励起と考えた. 図 $6 \mathrm{~b} に \mathrm{x}=0.15$ の運 動量依存性を示す。ここでは, スペクトルを弾性散乱 (緑 一点鎖線), バンド内励起 (赤長波線), モットギャップを 越える励起 (黄色二点鎖線), より高エネルギーにある励 起の裾 (扊色短破線) で解析した。 その結果からわかるよ うに, 電子ドープによって出現したバンド内励起は大きな 分散をもっている. 図6cには運動量・エネルギーに対す る RIXS 強度マップを示す. $\mathbf{q} \|=(0,0)$ 付近で $2 \mathrm{eV}$ にあ るピークがモットギャップを越える励起, $\mathbf{q} \|=(0,0)$ か ら立ち上がる分散をもった励起がバンド内励起である. 図6bと同様の方法で求めたバンド内励起のピーク位置を 図6cに重ねると, 薄赤口のような分散になる。この実験 を行った 2004 年当時のエネルギー分解能は約 $400 \mathrm{meV}$ で あり, $\mathbf{q}_{\|}=(0,0)$ の近傍, エネルギーにしておよそ $1 \mathrm{eV}$ 以下の励起は観測できていなかった。

\subsection{2 軟X線非弾性散乱（銅 $\mathrm{L}_{3}$ 吸収端 RIXS）}

図3bでは, 単一スピン反転励起と $d d$ 励起の間にあ るスペクトル強度を, 母物質では主として two magnon 励起によるものと考えた. ラマン散乱の実験では, two magnon励起は電子ドープともに強度が失われることが 
観測されており,15)電子ドープされた物質のRIXSでの単 一スピン反転励起と $d d$ 励起の間にあるスペクトル強度 は母物質と同じ two magnon励起によるものとは考えにく い.さらに，母物質の two magnon励起はほとんど運動量 依存性がないのに対し, 図3cに示すとおり, ドープされ た物質の励起は，大きな分散がある. $\mathrm{x}=0.15$ について， そのピーク位置を図 $4 b$ にプロットすると, 赤いくのよう
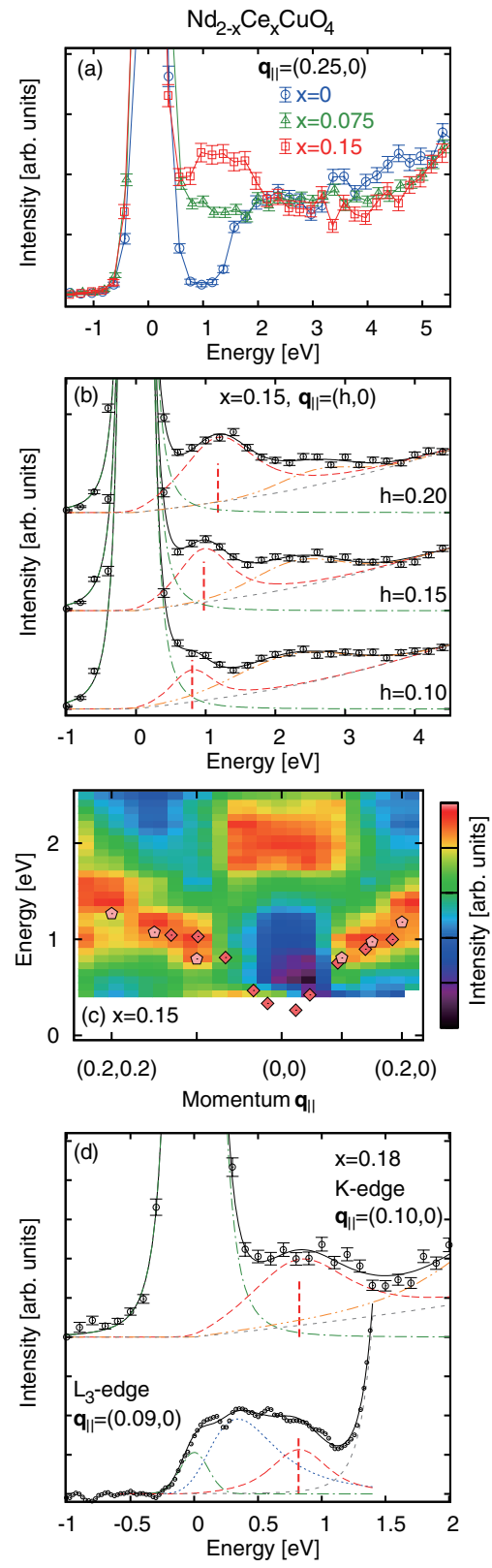

図6 $\mathrm{Nd}_{2-\mathrm{x}} \mathrm{Ce}_{\mathrm{x}} \mathrm{CuO}_{4}$ の銅 $\mathrm{K}$ 吸収端RIXS. (Cu K-edge RIXS of $\mathrm{Nd}_{2-\mathrm{x}} \mathrm{Ce}_{\mathrm{x}} \mathrm{CuO}_{4}$. $)$ (a) $\mathbf{q}_{\|}=(0.25,0)$ におけるドーピ ング依存性.（b)超伝導組成 $(\mathrm{x}=0.15)$ の運動量依 存性 $(\mathrm{c}) \mathrm{x}=0.15$ の RIXS 強度マップ. 赤い は，それぞれ銅K吸収端 RIXS，銅 $\mathrm{L}_{3}$ 吸収端 RIXS で得られた電荷励起のピーク位置を表す. (d) 高 エネルギー分解能での銅 $\mathrm{K}$ 吸収端 RIXS と銅 $\mathrm{L}_{3}$ 吸 収端RIXSの比較. (b) と (d) 中の線はフィッティ ングによる解析結果で, 詳細は本文中に記す。赤 長波線の棒は電荷励起のピーク位置を表す.

編集部注：カラーの図はオンライン版を参照下さい.
な運動量依存性になる. スピン励起よりも大きな分散を もって $\mathbf{q}=(0,0)$ から立ち上がっていることがわかる. 同じものを銅K吸収端 RIXS の強度マップの上にプロッ トすると図6cのようになる。一見してわかるとおり，銅 $\mathrm{L}_{3}$ 吸収端 RIXS で得られた励起の分散 ( ) は, 銅 K吸収 端RIXS で得られた励起の分散（口）に滑らかにつながっ ている。このことから，われわれは両者が同じ起源をも つ電荷励起であると結論づけた。 電荷励起, スピン励起 のエネルギースケールが, それぞれ移動積分 $(t=0.3 \sim$ $0.4 \mathrm{eV})$, 交換相互作用 $(J=0.1 \mathrm{eV})$ に支配されているこ とを考えると, 電荷励起がスピン励起よりも大きな分散 をもち, 高エネルギーに現れることは妥当である.

最近のエネルギー分解能が改善された銅K吸収端 RIXS では，銅 $\mathrm{L}_{3}$ 吸収端RIXS で観測された励起と同じエ ネルギーでの観測がいくらか可能になりつつある。図6d では, $\mathrm{x}=0.18$ につて, ほぼ同じ運動量で銅 K吸収端 RIXS と銅 $\mathrm{L}_{3}$ 吸収端 RIXS のスペクトルを比較した。銅 $\mathrm{K}$ 吸収端 RIXS のエネルギー分解能は $250 \mathrm{meV}$ で銅 $\mathrm{L}_{3}$ 吸収 端 RIXS とほほ同じである。赤長破線で示す電荷励起は, 両スペクトルでほぼ同じエネルギーにあることがわかる。

\section{3 ホールドープ系との比較}

以上のように, スピン励起については INS と銅 $\mathrm{L}_{3}$ 吸収 端 RIXS，電荷励起については銅 $\mathrm{L}_{3}$ 吸収端 RIXS と銅 $\mathrm{K}$ 吸収端 RIXS を組み合わせて測定することで，電子ドー プ系銅酸化物超伝導体のサブ $\mathrm{eV}$ 領域におけるスピン . 電荷励起の全体像を明らかすることができた。これまで にわかっているホールドープ系の結果と合わせて図7に 励起の概略をまとめた。

ホールドープ系のおよそ $0.15 \mathrm{eV}$ 以上の高エネルギー スピン励起は, 最近の銅 $\mathrm{L}_{3}$ 吸収端 RIXS でその詳細が明 らかになった.12),16) ドーピングにより幅が広がるという 点は電子ドープ系と共通であるものの, その運動量依 存性は母物質のスピン波からほとんど変化しておらず, ドーピングにより高エネルギーにシフトする電子ドープ

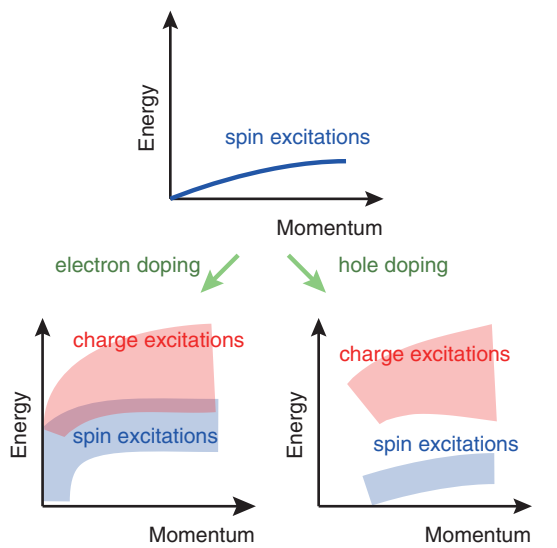

図7 銅酸化物超伝導体におけるスピン·電荷励起, および そのドーピング効果. (Spin and charge excitations in copper oxide supeconductors and their doping effect.) 
系とは対照的である。この結果は, ホールドープ系のス ピン励起は母物質の局在スピンの特徴を残しているのに 対し, 電子ドープ系では電子がより動きやすい遍歴的な 性質を帯びてきているものと考えられる. 最近の理論研

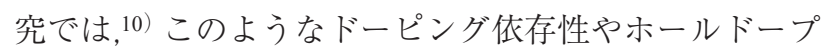
系と電子ドープ系の違いを説明するためには, 三体での 交換相互作用を考える必要があるという指摘がなされて いる，そのような高次の相互作用が超伝導にどのように 寄与しているかは, 今後の課題である.

一方, 電荷励起については, 共鳴条件をうまく選択す る必要があったために, 動的電荷相関に対応するような 分散をもったバンド内励起がホールドープ系の銅 K吸収 端RIXSで見つかった ${ }^{17)}$ のは最近のことである.およそ $1 \mathrm{eV}$ 以上の範囲では, 電子ドープ系と定性的には同じよ うな分散をもっている。一方, 銅 $\mathrm{L}_{3}$ 吸収端 RIXS の実験 は次々と報告されてきているものの, サブ $\mathrm{eV}$ 領域の電 荷励起については, 今のところそれを捉えたという報告 はなされておらず, 未知のまま残されている。

\section{4. まとめと今後の展望}

以上のとおり, 電子ドープ系銅酸化物超伝導体のスピ ン・電荷励起を調べる上で, マルチプローブ（X線と中 性子）を使った非弾性散乱実験が役立った。そこには, 「スピン励起をINSとIXSで調べる」というエネルギー (および運動量)によるものと,「スピン励起をINSで電 荷励起とIXS で調べる」という励起の種類によるものと の，2つの役割分担がある.さらに，今回の実験で観測さ れた励起を解釈していく上で, 理論計算が重要な役割を 果たしていたことも付記しておく.

電子励起を観測するための非弾性散乱, 特にRIXSの 技術は今も発展を続けている. 特に, 軟X線のRIXSに ついては世界各地で新しい分光器が建設されており, さ らなるエネルギー分解能の向上が期待されている.一方, 硬X線の RIXS のエネルギー分解能は軟 $\mathrm{X}$ 線の先を行っ ており, 銅 K吸収端では数年前にすでに $38 \mathrm{meV}$ という報 告18）がある。これから先数年の間に, $10 \sim 100 \mathrm{meV}$ に ある励起が研究対象となってくると期待され, 銅酸化物 超伝導体では, 図1aに示すようにちょうど超伝導ギャッ プのエネルギースケールに対応してくることになる. 理 論的には, RIXSを使って超伝導の対称性が議論できる ということも示されている.19）また, これまでの実験で はほとんど行われていない散乱 X 線の偏光状態を区別し た測定も可能となってきており,20),21）励起の同定に役立 つであろう。また，中性子散乱技術の開発も着実に進ん でおり,より高エネルギーの励起スペクトルをより高い 分解能で測定する量的な進展だけでなく, 偏極中性子を 利用して高エネルギースピン摇らぎの縦横成分の分離を 行う質的進展も進みつつある. 今後のマルチプローブ利
用は，相補的な利用に留まらず，今回示した電子自由度 の多面性の解明から本質に迫るといった, より深い融合 利用が進むと期待している.

\section{謝 辞}

本研究は, 佐々木隆了, Matteo Minola, Greta Dellea, Claudio Mazzori, Kurt Kummer, Giacomo Ghiringhelli, Lucio Braicovich, 遠山貴己, 堤 健之, 佐藤研太朗, 梶 本亮一, 池内和彦, 山田和芳, 吉田雅洋, 黑岡雅仁, 水 木純一郎各氏との共同研究として行われました。ここに 感謝致します。

\section{文 献}

1）藤井保彦：日本物理学会誌 46, 1056 (1991).

2) B. J. Kim et al.: Science 323, 1329 (2009).

3) Section 3.2 in K. Ishii et al.: J. Phys. Soc. Jpn. 82, 021015 (2013).

4）野田幸男：放射光 11, 3 (1998).

5) K. Ishii et al.: Nat. Commun. 5, 3714 (2014).

6) L. J. P. Ament et al.: Phys. Rev. Lett. 103, 117003 (2009).

7) L. Braicovich et al.: Phys. Rev. Lett. 104, 077002 (2010).

8) K. Ishii et al.: Phys. Rev. Lett. 94, 207003 (2005).

9) C. J. Jia et al.: New J. Phys. 14, 113038 (2012).

10) C. J. Jia et al.: Nat. Commun. 5, 3314 (2014).

11) M. Guarise et al.: Phys. Rev. Lett. 105, 157006 (2010).

12) M. Le Tacon et al.: Nat. Phys. 7, 725 (2011).

13) M. Fujita et al.: J. Phys. Soc. Jpn. 75, 093704 (2006).

14) K. Ishii et al.: J. Phys. Chem. Solids 69, 3118 (2008).

15) Y. Onose et al:: Phys. Rev. B 69, 024504(2004).

16) M. P. M. Dean et al.: Nat. Mater. 12, 1019 (2013).

17) S. Wakimoto et al.: Phys. Rev. B 87, 104511 (2013).

18) H. Yavas et al.: Nucl. Instrum. Methods Phys. Res. A 582, 149 (2007).

19) P. Marra et al.: Phys. Rev. Lett. 110, 117005 (2013).

20) K. Ishii et al.: Phys. Rev. B 83, 241101 (2011).

21) L. Braicovich et al.: Rev. Sci. Instrum. 85, 115104 (2014).

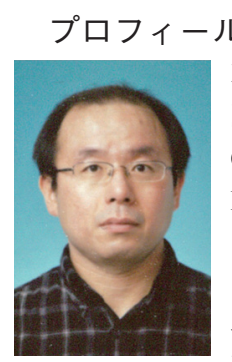
石井賢司 Kenji ISHII 日本原子力研究開発機構量子ビーム応用研究センター Quantum Beam Science Center, Japan Atomic Energy Agency

干 679-5148 兵庫県佐用郡佐用町光都 1-1-1

1-1-1 Kouto, Sayo, 679-5148 Hyogo, Japan 専門分野: 固体物理学

現在の研究テーマ: 放射光X線散乱による強相 関電子系の研究

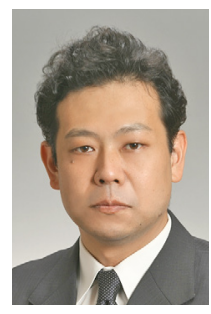

藤田全基 Masaki FUJITA 東北大学金属材料研究所 Institute for Materials Research, Tohoku University 干 980-8577 宮城県仙台市青葉区片平 2-1-1 2-1-1 Katahira, Aoba-ku, Sendai 980-8577, Japan 専門分野: 固体物理学 現在の研究テーマ: 中性子散乱による強相関電 子系のダイナミクス研究 